University of Nebraska - Lincoln

DigitalCommons@University of Nebraska - Lincoln

Faculty Papers and Publications in Animal

Science

Animal Science Department

March 1983

\title{
INDEX SELECTION AND FEED INTAKE RESTRICTION IN SWINE. I. EFFECT ON RATE AND COMPOSITION OF GROWTH
}

\author{
Erik R. Cleveland \\ University of Nebraska-Lincoln \\ R. K. Johnson \\ University of Nebraska-Lincoln, rjohnson5@unl.edu \\ R. W. Mandigo \\ University of Nebraska-Lincoln, rmandigo1@unl.edu
}

Follow this and additional works at: https://digitalcommons.unl.edu/animalscifacpub

Part of the Animal Sciences Commons

Cleveland, Erik R.; Johnson, R. K.; and Mandigo, R. W., "INDEX SELECTION AND FEED INTAKE

RESTRICTION IN SWINE. I. EFFECT ON RATE AND COMPOSITION OF GROWTH" (1983). Faculty Papers

and Publications in Animal Science. 27.

https://digitalcommons.unl.edu/animalscifacpub/27

This Article is brought to you for free and open access by the Animal Science Department at DigitalCommons@University of Nebraska - Lincoln. It has been accepted for inclusion in Faculty Papers and Publications in Animal Science by an authorized administrator of DigitalCommons@University of Nebraska - Lincoln. 


\title{
INDEX SELECTION AND FEED INTAKE RESTRICTION IN SWINE. I. EFFECT ON RATE AND COMPOSITION OF GROWTH ${ }^{1}$
}

\author{
Erik R. Cleveland ${ }^{2}$, R. K. Johnson ${ }^{3}$ and R. W. Mandigo ${ }^{3}$ \\ University of Nebraska, Lincoln 68583
}

\section{Summary}

The objectives of this experiment were to determine the effects of index selection for increased average daily gain and decreased backfat, and the effects of restriction of daily feed intake, on rate and composition of growth in swine. A total of 53 barrows from select and control lines were randomly assigned to three feeding levels at $83 \mathrm{~d}$ of age, and 33 littermate barrows were slaughtered to establish initial body composition. The trial was approximately $105 \mathrm{~d}$ and the feeding levels were twice daily to appetite (AP), once daily feeding of $91 \%$ of appetite (AP91) and once daily feeding of $82 \%$ of appetite (AP82). At slaughter, all pigs were dissected and analyzed for chemical composition. Average daily gain was higher $(P<.01)$ while backfat was lower $(\mathrm{P}<.001)$ for select than for control pigs. Restriction of feed intake reduced $(P<.01)$ growth rate. Even at heavier final weights, select pigs had a greater $(P<.001)$ proportion of lean than control pigs. Pigs fed the AP91 and AP82 levels of intake had a greater $(P<.01)$ proportion of lean than pigs fed the AP level. Daily gains of protein, water and lean were higher $(\mathrm{P}<.01)$ for select than for control pigs. However, daily fat gain was lower $(\mathrm{P}<.05)$ for select pigs. Restricting feed intake reduced $(\mathrm{P}<.05)$ daily fat gain, but daily gains of protein, water and lean were similar for pigs on the AP and AP91 levels. However, daily gains of protein, water and lean were lower for pigs on the AP82 level than for those on the other regimens. (Key Words: Swine, Selection, Intake, Growth, Composition.)

\section{Introduction}

Improved conversion of dietary energy into carcass lean should be a major objective of long term swine improvement programs. Unfortunately, the results of experiments in which there was direct selection for food conversion ratio are disappointing in that little change occurred (Dickerson and Grimes, 1947; Jungst et al., 1981). However, index selection for increased growth rate and decreased backfat thickness has been effective (Ollivier, 1977, Sather and Fredeen, 1978; Vangen, 1979, 1980).

Moderate restriction of daily feed intake reduces rate of fat growth more than the rate of lean growth of market pigs (Cöp, 1974). It is a common practice in many countries, but is not widespread in the United States. However, restricting the intake of growing pigs may become a useful management practice, particularly if feed costs rise more rapidly than other production costs. Optimum feed restrictions may depend on the rate and composition of growth and may differ for different genetic stocks.

Cleveland et al. (1982) reported the results of five generations of index selection for increased postweaning average daily gain and decreased backfat. Average daily gain increased by $12.5 \%$ and backfat decreased by $5.4 \%$. The objectives of the present experiment were to evaluate the effects of index selection for increased growth rate and decreased backfat and the effects of restriction of daily feed intake on the rate, efficiency and composition of growth.

\section{Materials and Methods}

Populations. From 1958 to 1965, the University of Nebraska Gene Pool population was established by the introduction of 13 breeds of swine into a Hampshire female

\footnotetext{
'Published as Paper No. 6867, Journal Ser., Nebraska Agr. Exp. Sta.

${ }^{2}$ Present address: Univ. of Georgia, Rural Development Center, Tifton 31793.

${ }^{3}$ Anim. Sci. Dept.
} 
population (Zimmerman and Cunningham, 1975). The 14 breed synthetic population was closed in 1965 and maintained by random mating until the initiation of an ovulation rate selection experiment in 1967. Third generation ovulation rate select and control line boars and sows were reciprocally crossed and the litters, born during 1971, formed generation 0 select and control lines to evaluate index selection for increased postweaning average daily gain (ADG) and decreased backfat (BF).

Cleveland et al. (1982) reported the results of five generations of index selection for ADG and BF. Ad libitum feeding over the interval of $56 \mathrm{~d}$ to $79 \mathrm{~kg}$ was used and the index was: $\mathrm{I}=$ $100+286.6$ (ADG) $-39.4(\mathrm{BF})$. The highest indexing generation 5 progeny from the select line were mated and Caesarian section-derived litters (by 10 different sires) were used to repopulate the line in new swine facilities. At the same time, the ovulation rate control line. was repopulated with Caesarian section-derived litters produced by mating randomly selected generation 8 boars and sows. Following repopulation, the lines were maintained by random selection and random mating. The index control line was not repopulated. Differences between the ovulation rate select and control lines have been small for daily gain, probe backfat (Newton et al., 1977) and carcass traits (England et al., 1977). Therefore, the ovulation control line was deemed to be an acceptable control for the index line. The present experiment compares a random sample of index select barrows with ovulation rate control line barrows. Litters were born during 1979 and represent six generations of index selection followed by one generation of relaxed selection.

Experimental Procedure. After weaning at $28 \mathrm{~d}$ of age, 86 barrows were maintained in nursery facilities until they were about $75 \mathrm{~d}$ of age. They were moved to an environmentally controlled individual feeding unit and, at a mean age of $83 \mathrm{~d}(\mathrm{SD}=4.5)$, they were weighed and ultrasonically probed for backfat thickness. The mean starting weight was $25.3 \mathrm{~kg}$ (SD $=6.6$ ). Fifty-three barrows ( 23 index select and 30 control line) were randomly allotted within line and fed twice daily to appetite (AP), $91 \%$ of appetite intake (AP91) or $82 \%$ of appetite intake (AP82). Once daily feeding was used for AP91 and AP82 treatments. The other 33 barrows were slaughtered to establish the initial body composition of the lines. The initial slaughter sample (9 index and 24 control line) included at least one barrow from each litter represented by the test group. The litters were produced by eight index and 15 control line sires.

Pigs on the AP regimen were given access to the feeder for two 1-h periods/day. Body weight and feed intake were measured weekly, and average daily feed intake for the week was regressed on midweek weight. Pigs on the AP91 and AP82 regimens also were weighed weekly and, based on the AP regression equations, their average daily feed intake was calculated for the next week.

During the next week, pigs on the AP91 and AP82 regimens were given one feeding/day of 91 or $82 \%$, respectively, of the calculated AP intake. The diet was $16 \%$ protein corn-soybean meal (table 1); and pigs were fed for approximately $105 \mathrm{~d}(\mathrm{SD}=3.3)$, after which they were weighed, ultrasonically probed for backfat and slaughtered. Two feedings/day (AP) vs one feeding/day (AP91 and AP82) was confounded with feeding regimen. Possibly, this could affect results. However, Friend and Cunningham (1964) fed pigs the same quantity of food in one meal or five meals/day and found little effect of frequency of eating on efficiency of calorie conversion to fat and protein gain or on

TABLE 1. COMPOSITION OF DIET

\begin{tabular}{|c|c|}
\hline Component & Percentage \\
\hline $\begin{array}{l}\text { Corn } \\
\text { (IFN 4-02-992) }\end{array}$ & 75.46 \\
\hline $\begin{array}{l}\text { Soybean meal, } \\
44 \% \text { crude protein } \\
\text { (IFN 5-04-604) }\end{array}$ & 20.93 \\
\hline $\begin{array}{l}\text { Dicalcium phosphate } \\
\text { (IFN 6-01-080) }\end{array}$ & 1.42 \\
\hline $\begin{array}{l}\text { Limestone } \\
\text { (IFN 6-02-632) }\end{array}$ & .64 \\
\hline $\begin{array}{l}\text { Iodized salt } \\
\quad \text { (IFN 6-04-151) }\end{array}$ & .50 \\
\hline Trace mineral mix ${ }^{a}$ & .05 \\
\hline Vitamin premix ${ }^{b}$ & 1.00 \\
\hline Total & 100.00 \\
\hline
\end{tabular}

${ }^{\mathrm{a}}$ Contributed the following in $\mathrm{mg} / \mathrm{kg}$ of diet: $\mathrm{Zn}$, $100 ; \mathrm{Fe}, 50 ; \mathrm{Mn}, 27.5 ; \mathrm{Cu}, 5.0 ; \mathrm{Co}, .5 ; \mathrm{I}, .75$.

${ }^{b}$ Contributed the following per $\mathrm{kg}$ of diet: vitamin A, 3,300 units; vitamin $B_{12}, 22.05 \mu \mathrm{g}$; vitamin $D_{3}$, $440 \mathrm{ICU}$; vitamin E, $22.05 \mathrm{IU}$; riboflavin, $2.2 \mathrm{mg}$; D-pantothenic, $13.23 \mathrm{mg}$; niacin, $17.64 \mathrm{mg}$; choline chloride, $110.23 \mu \mathrm{g}$; ethoxquin, $4.41 \mathrm{mg}$; menadione sodium bisulfate, $2.2 \mathrm{mg}$. 
the digestibility of the diet. The group fed once daily had a higher rate of live weight gain, which was attributed to the effect of fill, because carcass weight gains were similar for the two groups. Very small differences were found for carcass measurements.

Before slaughter, all pigs were held off feed for $36 \mathrm{~h}$. They were electrically stunned, the jugular vein was severed and all blood was collected. The head and hooves were removed and the carcass was skinned. Each pig was divided into four fractions. Fraction $\mathbf{A}$ included the blood, head, hooves, hair, skin and minimal fat removed while skinning. All viscera were included in fraction B. Hot carcasses were dissected into fraction $C$, the edible lean and fat, and fraction $\mathrm{D}$, the bone, cartilage and minimal fat and lean that could not be removed from the bones.

Each fraction was thoroughly ground and blended and analyzed for fat, protein, ash and water (AOAC, 1975). The total weight of water, fat, protein and ash was calculated for each fraction of each animal, and the weight of each component in each fraction was summed to get the estimated weight of water, fat, protein and ash in the animal at the time of slaughter.

Data Analyses. For each pig in the initial slaughter group, fat, protein, water, ash and lean (protein + water + ash) for total carcass and for fraction $C$ were expressed as a percentage of $83-d$ weight. The percentages of each component were fitted to a model with the effects of initial weight and probe backfat. If an independent variable was not significant, it was deleted from the model and the data were reanalyzed. Preliminary analyses resulted in no significant line by regression coefficient interactions; thus, the regression coefficients were pooled within line. The regression coefficients (table 2) obtained from these analyses were used to estimate the 83-d composition of the littermate test pigs. The percentage of each component was estimated by:

Component percentage in test pig $=$ Component percentage in littermate +$$
\mathrm{b}_{\mathrm{C} \%} \cdot \mathrm{BF}\left(\mathrm{BF} \cdot \mathrm{TP}-\mathrm{BF}_{\mathrm{LM}}\right)+
$$$$
{ }^{b} \mathrm{C} \% \cdot \mathrm{WT}\left(\mathrm{WT}_{\mathrm{TP}}-\mathrm{WT}_{\mathrm{LM}}\right) \text {, }
$$

where,

$\mathrm{b}_{\mathrm{C}} \% \cdot \mathrm{BF}$ and $\mathrm{b}_{\mathrm{C}} \% \cdot \mathrm{WT}=$ regression coefficient of the component percentage on backfat (BF) or weight (WT), respectively, in the initial
TABLE 2. SIGNIFICANT REGRESSION COEFFICIENTS OF COMPOSITION PERCENTAGE ON BACKFAT AND WEIGHT FOR THE INITIAL SLAUGHTER GROUP

\begin{tabular}{llr}
\hline Trait & $\mathrm{b}_{\mathrm{BF}}^{\mathrm{b}}, \mathrm{cm}$ & $\mathrm{b}_{\mathrm{WT}}^{\mathrm{c}}, \mathrm{kg}$ \\
\hline Percentage & & \\
$\quad$ Fat & 11.00 & \\
Protein & & \\
Water & & -.257 \\
Ash & & -.267 \\
Lean & 6.14 & .093 \\
Fat in C & & .071 \\
Protein in C & .205 \\
Water in C & .002 \\
Ash in C & .278 \\
Lean in C & & \\
\hline
\end{tabular}

${ }^{\mathrm{a}} \mathrm{C}$ is fraction consisting of edible lean and fat.

${ }^{b} b_{B F}=$ regression of percentage of each component on backfat.

$c_{b_{W r}}=$ regression of percentage of each compon-
nt on weight.

slaughter group and TP and $L M$ designate the test pig and littermate, respectively.

The estimated percentage of each component and the initial weight of each test pig were used to estimate the total initial weight of each component in each test pig. The weight gain for each component was measured as the difference between the weight of the component in the test pig at slaughter and the estimated initial component weight.

All variables were analyzed with a model that included the effects of line, feeding level, line $x$ feeding level and initial test weight. The mean difference between the index and control lines, averaged over feeding levels, and the orthogonal contrasts among feeding levels of $1 / 2(\mathrm{AP}+\mathrm{AP} 91)$ vs AP82 and AP vs AP91 were calculated. The interaction of these contrasts with line were calculated, but were not significant for any trait. When not significant, initial weight was deleted from the model and the data were reanalyzed.

\section{Results}

Composition of Initial Slaughter Group. Line means for weight and composition of the body fractions in the initial slaughter roup are presented in table 3 . The initial slaughter 
sample of control barrows was $2.8 \mathrm{~d}$ older, and consequently, about $3 \mathrm{~kg}$ heavier than the sample of index barrows. Thus, the weight of each fraction was also heavier; however, the line difference was significant only for viscera weight (fraction B).

In general, the compositional differences between the lines were small. But protein percentage in control barrows was significantly higher in fractions $A, C$ and $D$. As a result, the percentage of protein in the total body was also significantly higher $(.7 \%)$ for control barrows. Index barrows had $2.3 \%$ less fat and $2.3 \%$ more water in the viscera than did control barrows.
Performance Traits. Initial weights, final weights and feed intakes are presented in table 4. Achieved levels of intake restriction were calculated within line by expressing intake $\cdot \mathrm{d}^{-1}$. midweight $^{-1}$ for pigs receiving the AP91 and AP82 feeding regimens as a percentage of the value for pigs on the AP level of feeding. Achieved restrictions for index and control barrows were 91.9 and $92.3 \%$, respectively, for the AP91 regimen and 86.5 and $84.6 \%$ for the AP82 regimen. The achieved restrictions were higher than target values for the AP82 regimen. However, intake per unit of midweight was very similar for index and control barrows on each

TABLE 3. LINE MEANS AND STANDARD ERRORS FOR WEIGHT AND COMPOSITION OF BODY FRACTIONS IN THE INITIAL SLAUGHTER GROUP

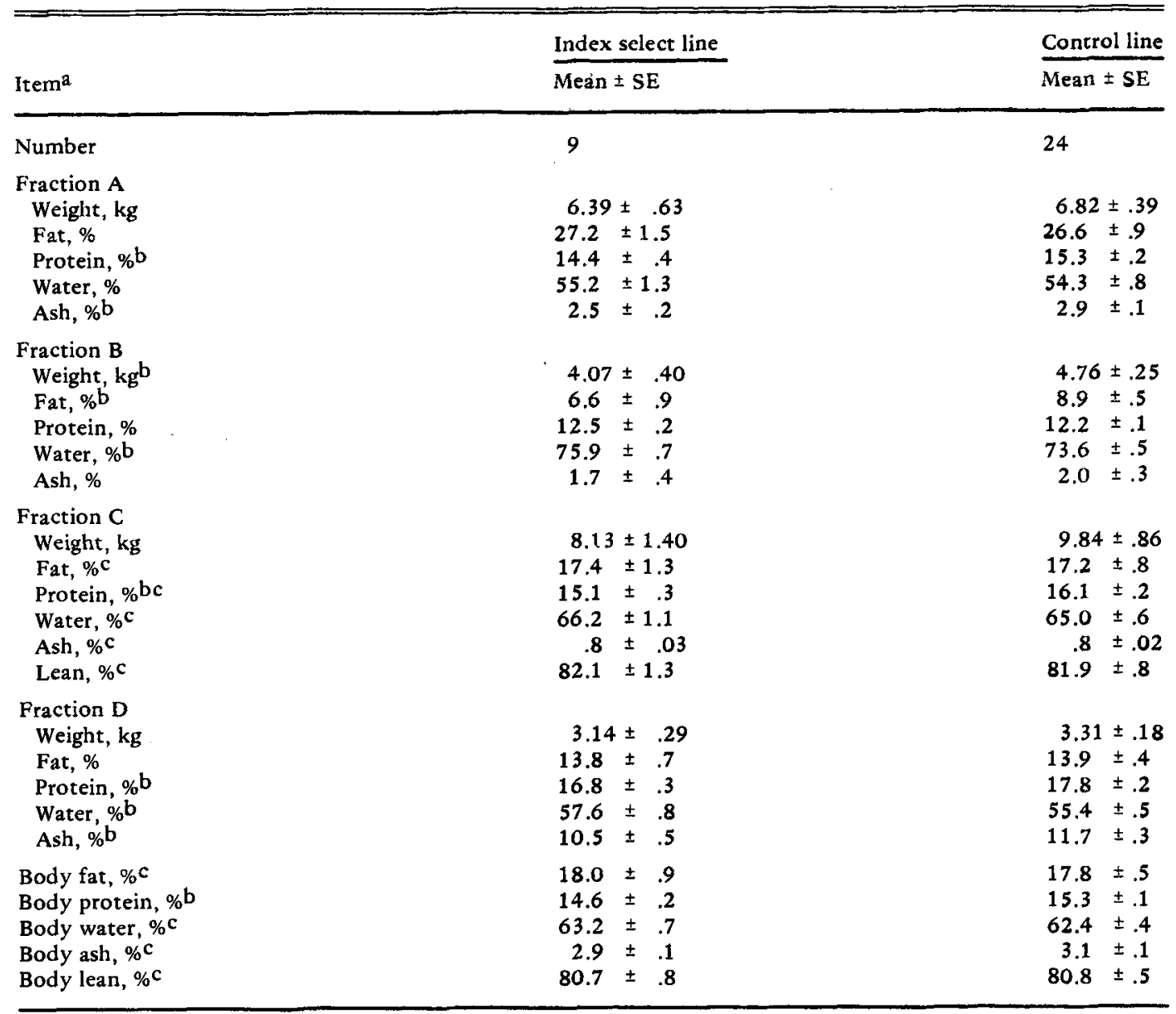

\footnotetext{
${ }^{a}$ Fraction $A$ = blood, head, skin, hair and hooves; fraction $B=$ viscera ; fraction $C=$ edible lean and fat and fraction $D=$ bone, cartilage and unseparable fat and lean.

$b_{\text {Line difference }(}(P<.05)$.

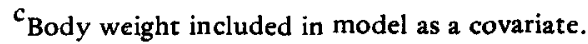




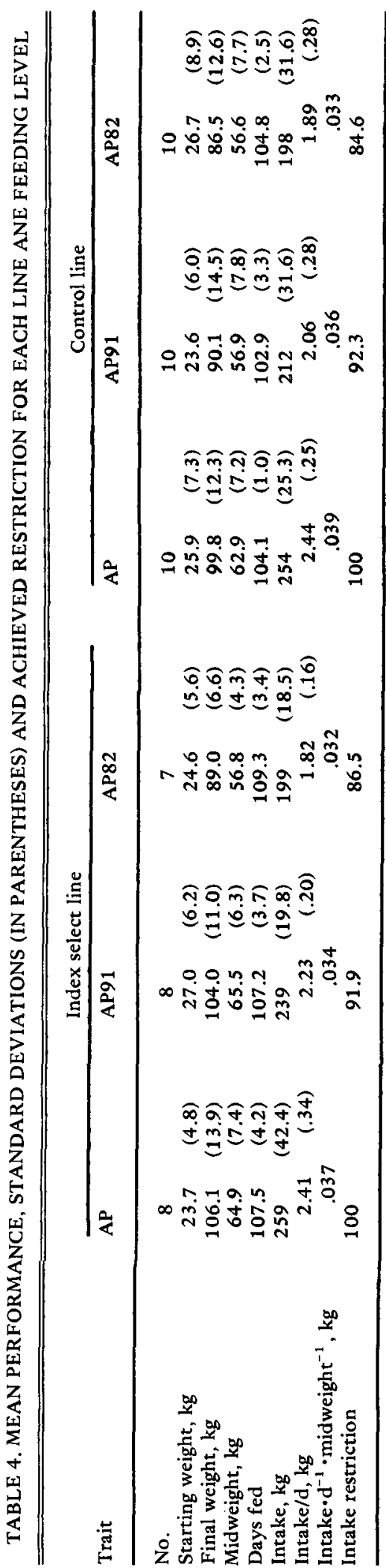

intake treatment. The greatest total weight gain was made by index barrows on the AP level of feeding, but because they were heavier at the start of the trial, midweight was greatest for index barrows on the AP91 level of intake.

Composition of the Test Pigs. The weights of fractions $A, C$ and $D$ were heavier for index barrows than for control barrows (table 5), due largely to heavier final weights for the index line. However, viscera weight (fraction B) was slightly less for the index line, although the difference was not significant.

Index barrows had significantly less fat in each fraction than did control barrows. They also had significantly more water in fractions A, $B$ and $C$ and more water in fraction $D$ (carcass bone and cartilage), although the difference was not significant. Index barrows also had significantly more protein in fractions $\mathrm{B}, \mathrm{C}$ and $\mathrm{D}$ than did control barrows. The percentage of protein in fraction A, however, was similar for both lines.

The index selection effectively improved carcass merit. The percentage of lean (water, protein and ash) in the edible portion of the carcass (fraction C) was $5.47 \pm 1.12 \%$ higher for index barrows. Significant line differences existed for each component, except ash, when expressed as a percentage of whole body weight (table 6). Index barrows had $3.63 \pm .71 \%$ less fat and $3.87 \pm .71 \%$ more lean in the whole body than control barrows. The improvement in percentage lean tissue was made up mostly of water, but there was also a significant line difference for protein percentage $(.70 \pm .17 \%)$.

Restricting intake significantly reduced final weight and consequently, the weight of each fraction was reduced (table 5). However, the effect of restricting intake was greater for the weight of fraction $\mathrm{C}$ (edible carcass lean and fat) than for the weight of other body fractions. Contrast 2 compares the average of AP and AP91 feeding levels with the AP82 level. The higher daily feed intakes caused significantly higher fat percentages in the viscera (fraction B) and in the carcass lean and fat tissue (fraction C). The fat percentage was also higher in fraction $\mathrm{A}$. The higher daily feed intakes also resulted in a significantly lower protein percentage in fraction $\mathrm{C}$ and significantly lower water percentages in fractions $B$ and $C$. The differences between AP and AP91 feeding levels (contrast 3) were significant for fat and water percentage in fraction $B$ and for percentage of fat, protein and water in fraction C. Compared 


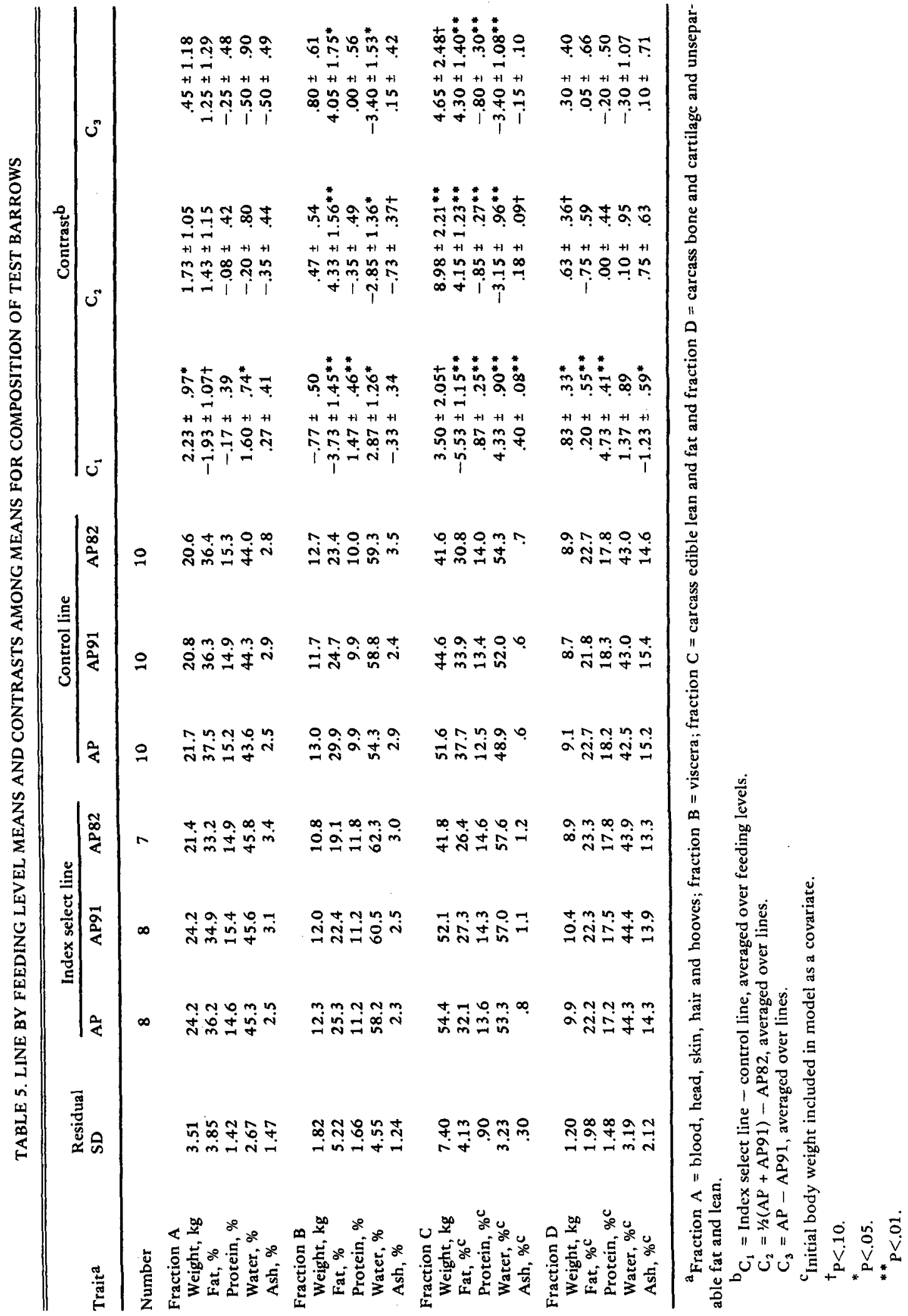




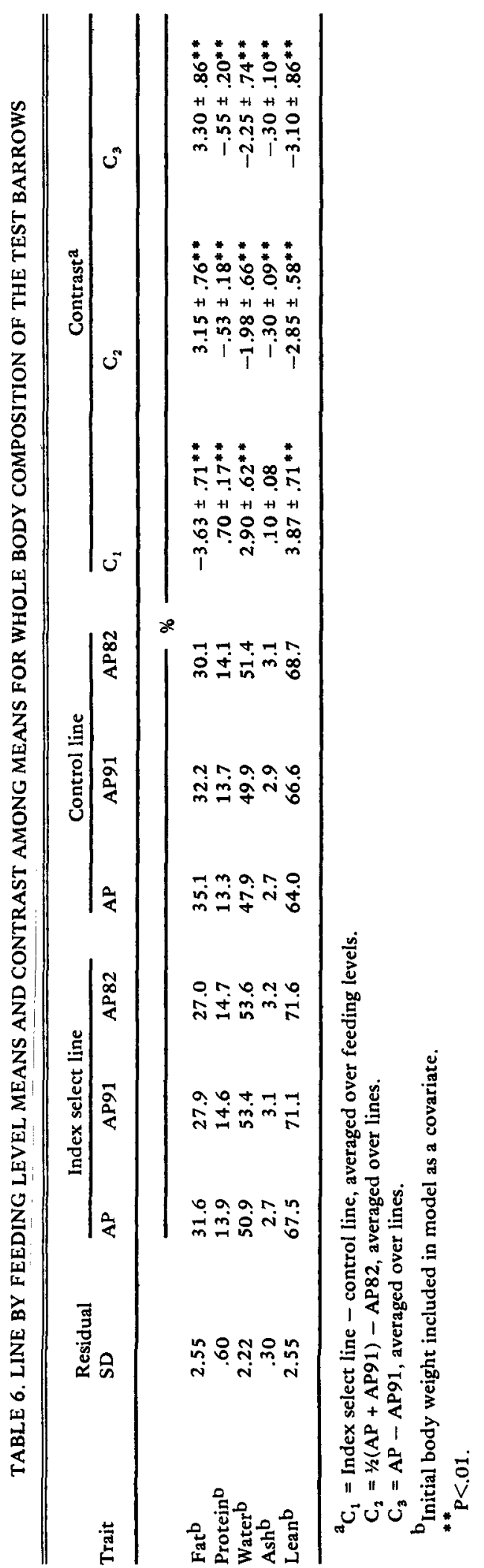

with the AP intake level, the $91 \%$ regimen significantly reduced the percentage of fat and increased the percentage of water in fractions $B$ and $\mathrm{C}$. The percentage of protein in fraction $\mathrm{C}$ was also higher for pigs on the AP91 feeding level.

No interactions of feeding level $x$ line were significant for the percentage of components in any fraction or in the whole body. The general effect of daily restrictions of feed intake was to significantly reduce the percentage of fat and to increase the percentage of lean (protein, water and ash) in the body (table 6). The first level of restriction, AP91 vs AP, caused the percentage body fat to decrease by 3.7 and $2.9 \%$ in index and control pigs, respectively. The second level of restriction, AP82 vs AP91, caused the percentage body fat to decrease by $.9 \%$ in index pigs and by $2.1 \%$ in control pigs. Lines that differ in rate and composition of growth probably are affected differently by different daily feed intake restrictions. However, the numbers in this experiment were not sufficient to detect significant interactions of this magnitude.

The lower percentage of fat in index pigs gave them a higher body water to fat ratio than control pigs $(1.86 \pm .04$ vs $1.58 \pm .04)$. Also, the fat to protein ratio was smaller for index than for control pigs $(2.02 \pm .05$ vs $2.39 \pm .05)$. The general effect of restricting feed intake was to increase the ratio of water to fat $(1.51,1.84$ and 2.10 for AP, AP91 and AP82, respectively) and decrease the ratio of fat to protein (2.47, 2.14 and 2.01, respectively). Neither feeding level nor selection background significantly influenced the ratio of water to protein, which ranged from 3.60 for control barrows on AP intake to 3.68 for index barrows on AP intake.

Daily Gain of Components. Daily gains of fat, protein, water, ash and lean in the body and in the carcass fat and lean tissue are presented in table 7 . Average daily gain and probe backfat are also presented.

Index pigs had less probe backfat and higher daily gains than control pigs. They deposited significantly less fat and more water and protein per day.

Restricting daily feed intake significantly reduced daily fat gain, which was reduced similarly by intake restrictions from AP to AP91 and AP91 to AP82. However, in both lines the daily gain of protein, water and lean was only slightly reduced when daily feed intake was restricted from the AP to the AP91 


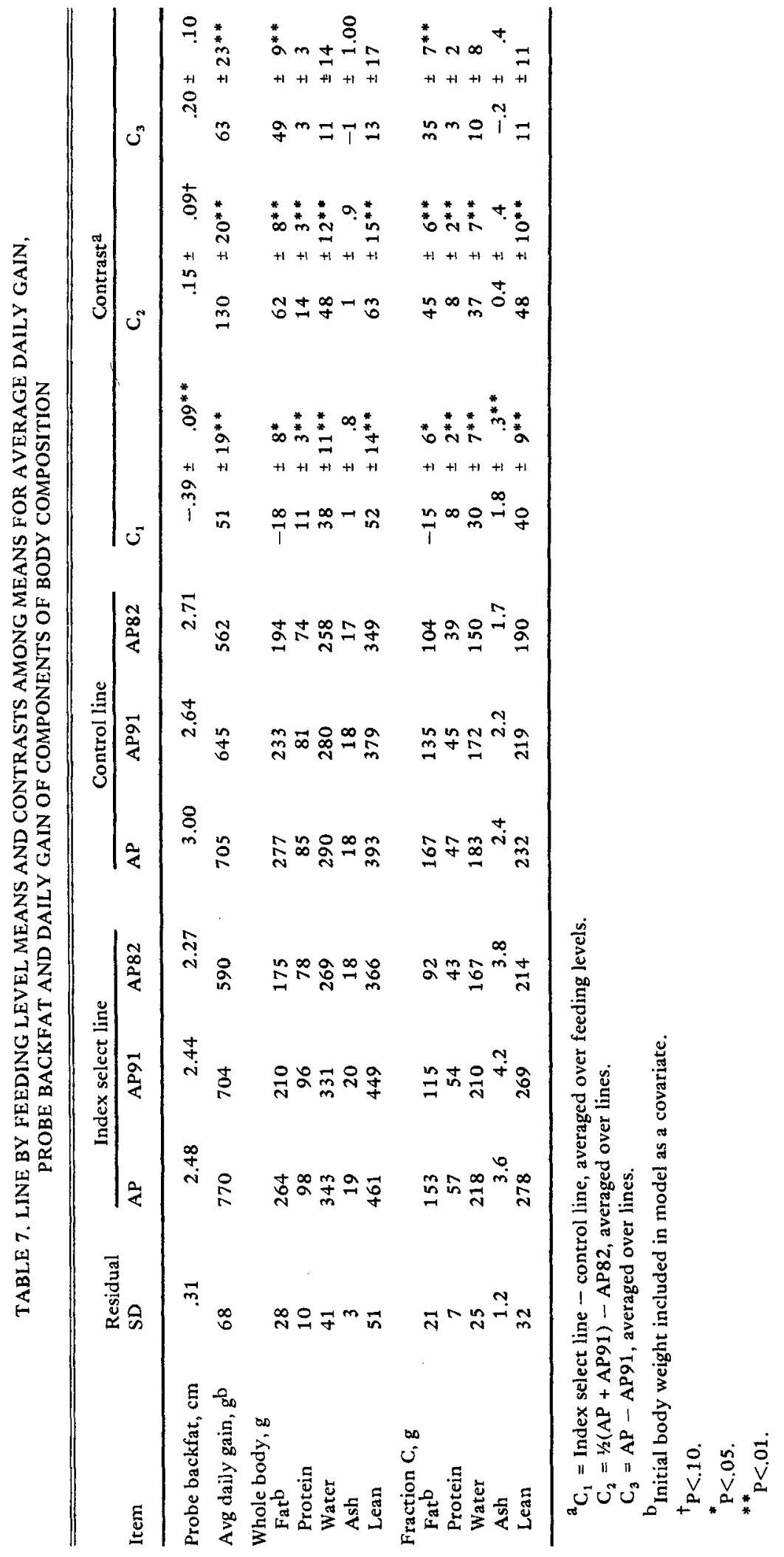


level. However, the index line exhibited a marked decline in daily gain of protein, water and lean when fed at the AP82 level.

\section{Discussion}

Index selection for average daily gain, measured over the interval of $56 \mathrm{~d}$ to $79 \mathrm{~kg}$, and probe backfat thickness at $79 \mathrm{~kg}$ increased the rate of growth from 83 to $188 \mathrm{~d}$ of age and resulted in more lean and less fat in market weight barrows. Ollivier (1977), Sather and Fredeen (1978) and Vangen (1979) also have reported that index selection for increased average daily gain and decreased backfat was effective. The general results of these four experiments are similar, but the relative change per generation in the component traits differs somewhat among experiments. This may be explained in part by different relative weightings on the component traits and by different testing procedures. The lines from this experiment differed in percentage body fat by $3.6 \%$. In contrast, after eight generations of index selection, Sundst $\emptyset$ l et al. (1979) reported that fat and lean growth lines differed by $6 \%$ in fat.

Cote and Wangsness (1978) observed that lean and obese pigs differed in fat to protein ratio. Similarly, the index select and control lines of this study differed in water to fat and fat to protein ratios. However, selection did not alter the ratio of water to protein. In accordance with the results presented by Lawrie (1974), the water content of lean tissue declined with age. The water to protein ratio in the body was 4.33 at $83 \mathrm{~d}$ of age and 3.65 at $188 \mathrm{~d}$ of age. In the edible fat and lean tissue of the carcass, this ratio declined from 4.38 at $83 \mathrm{~d}$ to 3.93 at 188 $d$ of age.

Restricting daily feed intake reduced average daily gain, decreased backfat thickness and improved composition of market weight barrows. Similar results have been reported by several other researchers (Hellberg, 1961; Vanschoubroek et al., 1967; Trapnell et al., 1978).

Although interactions were not significant, the index and control lines tended to respond differently to intake restrictions. Restrictions of feed intake caused similar reductions in both lines in daily fat deposition. However, line differences in protein and water gain were more pronounced for pigs fed the AP or AP91 feeding levels than for those fed the AP82 level. Daily protein intakes were calculated and compared with recommended levels (NRC,
1979). Daily protein intakes were adequate for all pigs except those fed the AP82 level. Select and control pigs on the AP82 regimen received approximately 88 and $93 \%$, respectively, of estimated daily protein requirement. The index line was leaner and should have had a higher protein requirement. Inadequate daily protein intakes should have had a greater effect on the daily rate of protein synthesis and lean deposition in fast-growing, lean lines than in slowergrowing, fatter lines. Also, the energy intake on the AP82 feeding level may have been so low that some dietary proteins were being catabolized for energy.

Index selection for rapid average daily gain and decreased backfat is effective for improving rate and composition of growth. An important question is whether or not the rate of improvement could be increased if some measure of feed intake were included in the selection index. M. Ellis and W. C. Smith (unpublished data) reported that selection on an index of average daily gain, backfat and food conversion ratio improved composition, but not rate of growth.

\section{Literature Cited}

AOAC. 1975. Official Methods of Analysis (12th Ed.). Association of Official Analytical Chemists, Washington, DC.

Cleveland, E. R., P. J. Cunningham and E. R. Peo, Jr. 1982. Selection for lean growth in swine. J. Anim. Sci. 54:719.

Cöp, W.A.G. 1974. Protein and fat deposition in pigs in relation to body weight gain and feeding level. Mededelingen Landbouwhogeschool, Wageningen, Nederland.

Cote, P. J., Jr, and P. J. Wangsness. 1978. Rate, composition and efficiency of growth in lean and obese pigs. J. Anim. Sci. 47:441.

Dickerson, G, E. and J. C. Grimes. 1947. Effectiveness of selection for efficiency of gain in Duroc swine. J. Anim. Sci. 6:265.

England, M. E., P. J. Cunningham, R. W. Mandigo and D. R. Zimmerman. 1977. Selection for ovulation rate in swine: Correlated response in carcass traits. J. Anim. Sci. 45:983.

Friend, D. W. and H. M. Cunningham. 1964. Effects of feeding frequency on metabolism, rate and efficiency of gain and on carcass quality of pigs. J. Nutr. 102:251.

Hellberg, A. 1961. Experiments with bacon pigs at different levels of nutrition. Proc. 8th. Int. Cong. Anim. Prod. p 258.

Jungst, S. B., L. L. Christian and D. L. Kuhlers. 1981. Response to selection for feed efficiency in individually fed Yorkshire boars. J. Anim. Sci. $53: 323$.

Lawrie, R. A. 1974. Meat components and their variability. In: D.J.A. Cole and R. A. Lawrie 
(Ed.) Meat. Proc. 21st Easter School in Agr. Sci., Butterworths, London.

Newton, J. R., P. J. Cunningham and D. R. Zimmerman. 1977. Selection for ovulation rate in swine: Correlated response in age and weight at puberty, daily gain and probe backfat. J. Anim. Sci. $44: 30$.

NRC. 1979. Nutrient Requirements of Domestic Animals, No. 2. Nutrient Requirements of Swine. Eighth Revised Ed. National Academy of Sciences-National Research Council, Washington, DC.

Ollivier, L. 1977. Dix ans d'une experience individualle sur des verrats utilises en insemination artificielle. 1. Response observees sur des caracteres de croissance de carcasse et de qualite de viande. Ann. Genet. Sel. Anim, 9:375.

Sather, A. P. and H. T. Fredeen. 1978. Effect of selection for lean growth rate upon feed utilization of market hogs. Can. J. Anim. Sci. 58:285.

Sundst $\phi 1$, F., N. Standal and O. Vangen. 1979. Energy metabolism in lines of pigs selected for thickness of backfat and rate of gain. Acta Agr. Scand. 29:337.

Trapnell, M. G., B. C. Cooke and M. K. Curran. 1978. The growth response of boars, gilts and castrates to different feed and protein levels. Anim. Prod. $26: 370$ (Abstr.).

Vangen, O. 1979. Studies on a two trait selection experiment in pigs. II. Genetic changes and realized genetic parameters in the traits under selection. Acta Agr. Scand. 29:305.

Vangen, $O$. 1980. Studies on a two trait selection experiment in pigs. III. Correlated responses in daily feed intake, feed conversion and carcass traits. Acta Agr. Scand. 30:126.

Vanshoubroek, F., R. DeWilde and P. Lampo. 1967. The quantitative effects of feed restriction in fattening pigs on weight gain, efficiency of feed utilization and backfat thickness. Anim. Prod. 9:67.

Zimmerman, D. R. and P. J. Cunningham. 1975. Selection for ovulation rate in swine: Population procedures and ovulation response. J. Anim. Sci. 40:61. 